\title{
TAITEEN JA TALOUDEN ARVOT
}

\author{
Dave Beech: Art and Value. Art's Economic \\ Exceptionalism in Classical, Neoclassical and \\ Marxist Economics. Historical Materialism \\ Book Series, Vol. 94. Brill: Leiden, Boston \\ 2015 .
}

Tuottaako taide arvoa kapitalismille, toteuttaako se erilaisia arvoja kuin talous tai onko taiteen kautta mahdollista ajatella arvon negaatiota? Dave Beech tutkii näitä kysymyksiä kirjassa Art and Value. Beechin mukaan tällä hetkellä vasemmisto ja oikeisto ovat valitettavan yksimielisiä taloustieteellisen selitysmallin kattavuudesta, eivätkä näe kapitalistisen arvontuotannon murtumakohtia, joita esimerkiksi taiteesta voitaisiin etsiä.

Kysymys taiteen ja talouden suhteesta vaatii monitieteistä lähestymistä. Kirjan ensimmäisessä osassa Beech kommentoi laajasti valtavirran talousteoreettista kirjallisuutta 1700-luvulta nykypäivään, ja toisessa osassa hän ottaa käsittelyyn marxilaisen taidefilosofian. Näistä lähtökohdista Beech hahmottelee teoriaa taiteen taloudellisesta poikkeuslaatuisuudesta. Kirja syntetisoi suuren määrän teoreettista kirjallisuutta ja on työnä kunnianhimoinen. Beech, joka on paitsi teoreetikko myös taiteilija, onkin nähtävästi päättänyt antaa takaisin ekonomisteille, jotka nykyään puhuvat usein taiteilijoista kun haluavat illustroida luovaa taloutta, kokeellisuutta ja innovatiivisuutta. ${ }^{1}$ Ei ole vaikea kuvitella, mistä kirja on saanut alkunsa: Beech ei varmasti ole ainoa taiteilija, joka on joskus puhissut: "Aina ne ekonomistit höpisee taiteesta, vaikkei ne tajua siitä mitään..." Jo tämän asetelman ympärikääntäminen on todella raikas ele. Lisäksi vaikka tässä kirjassa "taiteilija puhuu taloudesta", yritys ei ole naiivi ja projektilla on pitkä historia.

Art and Value -kirjan taustoja voi etsiä lähes 20 vuoden takaa. Vuonna 1996 Beech ja John Roberts julkaisivat New Left Review'ssa artikkelin "Spectres of the Aesthetic". Siinä he kritisoivat 1990-luvun johtavia taidefilosofeja ja -historioitsijoita estetismistä. ${ }^{2}$ Heidän mukaansa oleellista tälle uudelle estetismille on kantilainen väistöliike, jossa estetiikka tarjoutuu pseudo-ratkaisuksi subjektifilosofian ratkeamattomalle ristiriidalle epistemologian ja etiikan välillä. Etiikan sijaan kirjoittajat vaativat taideteorialta poliittista otetta. Beech ja Roberts nostavat esiin Andrew Bowien ja J.M. Bernsteinin luennan Theodor Adornosta ja rekonstruoivat tätä vastaan marxilaisen Adornon, erityisesti Esteettisen teorian kautta. Heidän mukaansa tässä kirjassa on idulla ei-kulttuurisesti ymmärrettyyn subjektiin kytkeytyvä, "filistiininen" taideteoria. Beech ja Roberts esittävät, että Adornon puolustama taiteen autonomia on itse asiassa ymmärretty väärin, subjektin autonomiaksi, kun se sen sijaan tulisi käsittää tiukasti taiteen käytäntöjen historialliseksi kokoonpanoksi ja suhteuttaa yhteiskunnallisen tekniikan kokonaisuuteen. Beechin ja Robertsin ohjelmarungossa autonomia onkin paradoksaalisesti jokapäiväisen modus. Kirjoittajille taideteorian politisointi ei siis palaudu instituutiokritiikkiin tai korkea/matala-erottelun kumoamiseen, vaan vaatii poliittis-teoreettista "partisaanin näkökulmaa". (Beech \& Roberts 2000.) Viime vuosina Roberts on jatkanut näiden teemojen käsittelyä kirjoissaan The Intangibilities of Form (2007) ja Revolutionary Time and the Avant-Garde (2015). Nyt käsillä olevassa kirjassa Beech palaa laajasti ottaen kulttuurin ja autonomian teemoihin, mutta jättää taideteorian sivurooliin ja keskittyy talousteoriaan. 
Beech lähtee liikkeelle modernin taloustieteen alkutaipaleelta. 1500- ja 1600-luvuilla arvon nähtiin syntyvän periaatteessa yhdestä lähteestä, merkantilismissa vaihdosta ja fysiokratiassa alkutuotannosta, eikä näissä teorioissa siten sanota juuri mitään kiinnostavaa taidekaupasta tai taiteentuotannosta, saati taiteen kulutuksesta. Modernin taloustieteen synnyn myötä 1700-luvulla vakiintuu kuitenkin näkemys kansantaloudesta, jossa työ hahmottuu tuotannoksi ja tuotanto tuottavuudeksi, jonka puolestaan voidaan nähdä koostuvan yksilösubjektien työteliäisyydestä.

Kuten Marx usein ironisesti osoittaa, poliittinen taloustiede Adam Smithistä lähtien on myös moraalioppia, tai oikeammin yleensä heikosti peiteltyä moralismia. Smith itse tosin korostaa taloustieteen olevan moraalitiede, mutta myöhemmin yhteys on useimmiten piilevä. Talousteoriaan vaikuttaa klassisen diskurssin alusta asti pyrkimys muuttaa deskriptiivinen preskriptiiviseksi kuvaamalla eitaloudellinen irrationaaliseksi ja taloudellinen luonnolliseksi.

Beechin mukaan Adam Smithistä alkaen klassisen taloustieteen teoreetikot sisällyttivät diskurssiinsa kuitenkin varauksia ja vastaesimerkkejä, joista yksi koskee taidetta. Smithillä, John Stuart Millillä, David Ricardolla ja muilla klassikoilla vastaesimerkeissä on useimmiten kyse hyödykkeistä, joiden tuotantoon, hintaan tai kysyntään on vaikea vaikuttaa. Kuuluisin esimerkki koskee parhaiden viinialueiden vuosikertaviinejä. Koska näitä on aina tarjolla vain rajoitetusti, kilpailu siirtyy tuotannosta kysynnän puolelle. Hintoihin ei voi vaikuttaa tuotantoa lisäämällä, joten hinta määrittyy käytännössä vain kysynnän alueella, jossa kattona toimii viime kädessä maksukyky. Taideteoksia koskee puolestaan toinen teoreetikolta toiselle kiertävä esimerkki, jonka muotoilee ensimmäisenä Ricardo. Hänen mukaansa parhaimmat taidemaalaukset vaativat niin poikkeuksellista taitoa, että työn kvantitatiiviseen arvoon alkaa vaikuttaa kvalitatiivinen osatekijä.Tässäkään tapauksessa tarjontaan ei käytän- nössä voi vaikuttaa tuotannon keinoin: taidon luonnollisen rajallisuuden tähden tarjonta on rajallista eikä myyjien kesken synny kilpailua. Kuten viinien kohdalla, ei taiteenkaan kysyntä putoa hintojen noustessa, vaan korkeat hinnat saattavat jopa lisätä kysyntää. Ricardo myöntää taiteen poikkeuksellisuuden, mutta ei pidä tilannetta vakavana. Englantilaisten taloustieteilijöiden piirissä Ricardon näkemys taiteen poikkeuksellisuudesta on kuitenkin merkittävä siksi, että hänen työnarvoteoriansa on klassikoista selkein ja muodostaa pohjan Marxin kriittiselle lisäykselle, joka tuo lisäarvon myötä arvojen moninaisuuden taloustieteeseen.

Kun muiden muassa William Stanley Jevons ja Friedrich von Wieser 1870-luvulla toivat laskevan rajahyödyn ja subjektiivisen valinnan käsitteet taloustieteelliseen keskusteluun, syntyi taloustieteen niin sanottu uusklassinen koulukunta, jota yhdisti klassisen taloustieteen taustaoletusten, ennen muuta klassisen työnarvoteorian, kritiikki. Tämä näkökulma talouteen muodostaa yhä perustan valtavirran talousdiskurssille. Laskevan marginaalihyödyn käsite siirtää huomion tuotannosta kysynnän tekijöihin, ja parhaiten se kuvaa hankintaa harkitsevan kuluttajan edeltävien ostopäätösten vaikutusta käsillä olevaan ostopäätökseen. Uusklassisen koulukunnan mukaan rajahyöty laskee kun hankinta toistetaan, sillä subjektiivinen tarve hankinnalle pienenee. Tuotannossa realisoituvat arvot eivät välttämättä vastaa kuluttajan arvoja, minkä takia uusklassiset teoreetikot painottavat kysyntää tarjonnan rekursiivisena korjaajana.

Beech panee merkille, että juuri uusklassisessa kirjallisuudessa taiteen erityisasema $\mathrm{ku}^{-}$ lutuksen ja tuotannon alueella kielletään. Kuitenkin myös laskevan marginaalihyödyn läpi katsottuna taide vaikuttaa poikkeukselliselta. Ongelma ilmenee kun verrataan nautinnan käsitteen referenttiä mustikoiden syömisen ja musiikin kuuntelemisen tapauksissa. Jos onkin selvää, että jokainen kourallinen mustikoita vähentää halua syödä lisää ja siten valmiutta maksaa seuraavasta kourallisesta sama hinta 
kuin edellisestä, musiikin kuuntelemisen kohdalla väite vaatii vähintäänkin tulkintaa. Lähinnä näyttää siltä, että tapauksesta riippuen taide voidaan ymmärtää yhtä hyvin tarpeen tyydyttäväksi objektiksi (konsertin kuuntelemisen jälkeen kaipaa hiljaisuutta) kuin addiktiiviseksi objektiksi (kirjan lukemista ei pysty lopettamaan, vaikka pitäisi mennä nukkumaan). Tästä epäselvyydestä voidaan johtaa tarkentava kysymys, joka koskee sitä, mitä taiteen "kysyntä" varsinaisesti on. Kuten Margaret Rose tuo esiin kirjassa Marx's Lost Aesthetic, Marx tekee Grundrissen johdannossa eron sekä taloustieteen että estetiikan traditioihin tarkastelemalla taidetta sosiaalisista tarpeista syntyvänä ja niihin vastaavana sosiaalisen tuotannon muotona (Rose 1984, 79-81). Tämä näkökulma tulee lähelle näkemystä, joka painottaa taiteen kokemista subjektiivisesti mielekkääksi. Beechin uusklassista taloustiedettä parodioiva heitto, jonka mukaan taiteen kohdalla "kysyntäkäyrä kääntyy odotusten vastaisesti nousuun" on osuva, muttei itsessään mikään laki. Kaiken kaikkiaan taiteen kokeminen ei selvästikään mallinnu standardihyödykkeiden kuluttamisen mallin mukaisesti, eikä siten ole kuluttamista sanan varsinaisessa mielessä. Voita tarvitaan leivän päälle, ja leipää tarvitaan elämiseen, mutta voin päälle ei voi laittaa taidetta. Taiteen arvostaminen on subjektiivista, eikä laskeva rajahyöty tai rationaalinen valinta tavoita sen ilmiötä. Tämä tekee taiteesta anomalian myös kulutukseen keskittyvälle talousteorialle. Ero Smithin ja Ricardon klassiseen talousdiskurssiin on siinä, että myöhemmin näkemys taiteen poikkeuslaadusta ei viimekätisestä ilmeisyydestään huolimatta yleisty, vaan siihen päätymistä ennemminkin lykätään.

Varhaisten uusklassisisten talousajattelijoiden joukosta Alfred Marshall panee kyllä merkille taidehyödykkeen poikkeuksellisen luonteen, mutta olettaa taidekulutusta ohjaavan maun pysyvän aina vakaana. Kun kulutus näin määritellään standardiksi, laskevan marginaalihyödyn malli voidaan pelastaa, mutta tämä johtaa taiteen subjektiivisen tekijän katoamiseen.
Marshallin puolinainen ratkaisu pohjustaa taiteen subjektiivisen ja kulutuksen objektiivisen osatekijän yhdistämistä kulttuurin ja maun käsitteissä, jotka saavat jatkossa päärooliin taloustieteellisissä ratkaisuyrityksissä taiteen subjektiivisuuden ongelmaan. Yksi Beechin kirjan ansioista onkin kuvata se historiallinen käänne, jossa maun ja kulttuurin kategoriat ikään kuin keksitään markkina- ja kulutustutkimuksen muodossa ratkaisemaan tämä problematiikka, vaikka kyseiset käsitteet on sitä ensin lainattu estetiikan ja sosiologian diskursseista.

Beech panee merkille, että edellä kuvailtu paradigmanvaihdos klassisesta uusklassiseen talousteoriaan pohjustaa toisen maailmansodan jälkeisen kehityskulun, jossa taiteen julkinen rahoitus nousee keskusteluun ainakin kahdesta eri näkökulmasta. Ensinnäkin valtiollisten apurahajärjestelmien, kuten Arts Councilin Isossa-Britanniassa, ja liberaalin taidekoulujärjestelmän syntyminen perustuvat ajatukselle, jonka mukaan markkinoiden itsesäätely ei riitä, vaan se tulee yhdistää valtiolliseen interventionismiin rajallisilla alueilla. Isossa-Britanniassa J.M. Keynesin merkitys sodanjälkeisen hyvinvointivaltioajattelun ulottamiselle taide- ja kulttuuripolitiikkaan on ilmeinen. Toisaalta Yhdysvalloissa 1960-luvulla eri taiteenalojen työvoimakustannuksia laskennallisesti tarkastelleen William Baumolin ja William Bowenin raportin myötä keskusteluun noussut kysymys elävää läsnäoloa vaativien taidemuotojen kustannusvajeesta on ollut keskeinen eri taidemuotojen tukemista koskeville ja myöhemmin myös julkisen sektorin palkkauksesta käydyille keskusteluille. "Baumolin tautina” tunnetuksi tulleen analyysin mukaan kustannusten nousu ja työn automatisaatio teollisilla aloilla syventää palkkakuoppaa niillä taidealoilla, jotka ovat työvoimapainotteisia. Klassinen esimerkki koskee Beethovenin jousikvarteton esityskustannusten melko pysyvää kulurakennetta vuosisadasta toiseen. Vaikka valtiollisiin tukitoimiin ei raportissa suoraan kannusteta, päätelmä häilyy rivien välissä, ja myöhemmin Baumol sekä muut ovat esittääneet sen suoraan myös 
julkisen sektorin tuottavuusvajeesta käydyssä kiistassa.

Beech katsoo yllä mainituissa keskusteluissa muodostuvan merkittävän, mutta lyhytkestoisen trans-atlanttisen konsensuksen, joka ensi kertaa pyrkii erottamaan taiteen ja kulttuurin epäkaupalliseksi ymmärretyn arvon markkina-arvosta. Taide ja kulttuuri tulevat toisen maailmansodan jälkeen ei-taloudellisesti ymmärretyiksi kahdessa mielessä. Ensinnäkin ymmärrys urbaanin elämän rakentamiseen sisältyvästä vieraantumisen vaarasta vahvistuu länsimaissa modernisaation, vaurastumisen ja kaupungistumisen myötä.Toisin sanoen elämän enenevä tavaroituminen johtaa tarpeeseen löytää tavaroitumiselle ulkopuoli. Toisaalta havaitaan, että erityisesti tunnettujen kuolleiden taiteilijoiden teosten taidekaupassa hinnanmuodostus ei tunne normaalihintaa, vaan prosessi on lähinnä stokastinen. Hinnanmuodostus ei heilahtele ja palaa normaaliin, vaan siinä aidosti ei ole normaalia. Tämän kannan tarkimmin muotoileva Baumol esittää, ettei taideteoksilla myöskään kuulu olla normaalia hintaa. Yhtäältä siis aletaan mieltää, kenties Marxin sosiaalisen tuotannon ajatusta mukaillen, että taide ja kulttuuri muodostavat vastavoiman urbaanin elämän vieraantuneisuudelle; toisaalta taas, että hinnanmuodostusprosessi taiteessa ei perustu mihinkään jalometallin arvon kaltaiseen ankkuriin, vaan että se on radikaalisti määrittämätön prosessi. Talousjärjestelmän finanssikriisit ja ilmastonmuutos aiheuttavat uusia shokkeja länsimaiselle episteemille, ja alkaa käydä ilmeiseksi, että vastoin taloustieteilijöiden väitteitä heidän tietonsa eivät päde kuin rajatulla alueella, eikä edes tämän alueen laajuutta tunneta.

Taiteen ja kulttuurin epäkaupallisuuden ajattelu saa 1970-luvun kuluessa osakseen kasvavaa kritiikkiä nousevassa cultural economics -diskurssissa, ja erityisesti siitä tulee Chicagon koulukunnan silmätikku. Beech huomauttaa, ettei kyse ole niinkään taiteesta ja kulttuurista, vaan siitä, voidaanko markkinamekanismille ylipäätään etsiä legitiimejä vaihtoehtoja. Käytännössä kyse on kampanjasta valtiollista interventionismia vastaan taide- ja kulttuuripolitiikan puitteissa. Beech kirjoittaa:

Väitän, ettei uusliberaalia agendaa taiteissa ole syytä ymmärtää niinkään intellektuaalisena kampanjana tai taloustieteen sisäisenä keskusteluna, jossa uusliberalistit saivat voiton, vaan globaalien rahoitusmarkkinoiden ja big businessin poliittisen kampanjan ulokkeena, vastauksena polttavaan taloudelliseen kysymykseen, joka koskee taiteen rahoituksen muuttuvia olosuhteita. Se, mikä ajoi taloustieteilijät mittavissa määrin tutkimaan taidetta, on nähdäkseni taiteen valtiollisen rahoitusmallin käyttöönotto, soveltaminen ja kasvu. (Beech 2015, 158-159. Suomennos TV.)

Chicagon koulukunnan kulttuuritaloustieteellisen tutkimuksen klassikkoteksteissä, kuten George Stiglerin ja Gary Beckerin vuoden 1977 artikkelissa "De Gustibus Non Est Disputandum" Marshallin staattisen maun ongelma ratkaistaan yksinkertaisesti esittämällä, että uusia muuttujia esittelemällä kulttuurinen toiminta voidaan palauttaa ekonomisen rationaliteetin alueelle.

Tästä tulee paradigmaattinen jäsennys kulttuurin uudelle taloustieteelle. Laskemalla varjokustannuksia ja varjohyötyjä kulttuuritoiminnalle, kuten konserteissa käymiselle, kirjoittajat tarjoavat musiikillisen (ja myöhemmin kulttuurisen) pääoman käsitteen laajennuksena laskevan marginaalihyödyn teorialle. Kiinnostavaa on, että esimerkiksi Pierre Bourdieu, joka oletettavasti pyrki 1970-luvulla eroon yhteiskuntatieteitä tällöin hallinneesta marxilaisesta työnarvoteoriasta, päätyy käytännössä sosiaalisen pääoman käsitteellä vahvistamaan uusliberaalia diskurssia, joka palauttaa taiteen ja kulttuurin arvon talouteen. Kriittisen sosiologian käsitteellistykset, kuten Bourdieun distinktio ja habitus, eivät viime kädessä pysty vastustamaan uusliberaalia diskurssia, koska ne vastustavat ortodoksista marxilaista diskurssia. Niinpä ne tulevat rakenteellisesti lähelle uusliberaalin taloustieteen keskustelua, kriittisten 
sosiologien omista pyrkimyksistä riippumatta. Tämä likeisyys näkyy ennen muuta pedagogisten ja taideinstituutioiden viestinnässä, kun ne pyrkivät yhdistämään kriittisen sosiologian pyrkimykset "aktivoida nuorisoa" käytännössä lyhentyvään taloudelliseen talutusnuoraan ja uusien tuottavuusmittareiden käyttööottoon.

Eräänlainen vedenjakaja taiteiden julkisen tuen uusliberaalissa kritiikissä on Alan Peacockin 1980-luvun puolivälissä Thatcherin hallitukselle laatima raportti BBC:n uudeksi rahoitusmalliksi, joka ajaa mainontaa, sponsoroitia ja kuluttajamaksuja valtiollisten lupamaksujen sijaan. Raportti hylättiin, mutta sen ajatukset jäivät vaikuttamaan. Näistä keskeinen on ajan hermoon osunut ajatus valtiollisen kulttuuripolitiikan holhoavasta luonteesta. Peacock painottaa subsidy-politiikan ja valtiollisen ohjauksen tuottavan kulttuurin ja taiteen piirissä elitististä vinoumaa, sillä kuluttajat eivät saa itse päättää, millaiseen taiteeseen ja kulttuuriin heidän verorahansa sijoitetaan. Kuluttajatutkimuksen käyttäminen ja kuluttajasegmenttien selvittäminen esitetään chicagolaisilla, kuten Beckerillä, yleensä demokraattisemmaksi ja kustannustehokkaammaksi kulttuuripolitiikan keinovalikoimaksi kuin elitistinen ja jäykkä valtiollis-alueellinen malli. Valtiollisesti ohjatun subsidy-politiikan kritiikin lisäksi usko markkinoiden itseohjautuvuuteen ja oletus kaikkien tuotteiden ja palveluiden viimekätisestä samanmuotoisuudesta ovat uusliberaalin cultural economics -paradigman avaintekijöitä. Vaikka mitattavuus tai tehokkuus eivät tarkasti ottaen tulisikaan taiteen ja kulttuurin alueella sovelletuiksi, puheentapoina ja ajattelun eetterinä ne läpäisevät kulttuuripolitiikan keskeiset toimijat taidepedagogiikasta taideinstituutteihin. ${ }^{3}$

Taiteen ja kulttuurin piirissä kamppailu on aina jo hävitty, kun taloudellisesti mitattavan tai sille analogisen "innovaatiotehokkuuden" keskusteluavaruuteen ajaudutaan, Beech painottaa. Ongelma on se, että vaikka melkein kaikki tietävät taloustieteen mittareiden kertovan lähinnä itsestään, mitään vaihtoehtoa niille ei ole tarjolla. Romanttinen puhe kulttuurin korkeammista arvoista ja sivistyksen itseisarvosta on toki tietyssä määrin sallittua, mutta ainoastaan kun se asettuu henkisenä suplementtina "kovia leikkauksia” toteuttaville uusliberaaleille uudistajille. Romantiikalle, sivistykselle ja kauneudelle on siis edelleen paikkansa taloudellisen rationaliteetin johtamassa taide- ja kulttuuripolitiikassa, ja se on taivaan sinessä.

Art and Value -kirjan toinen osa keskittyy marxilaisten taide- ja kulttuuriteorioiden arviointiin taiteen tuotannollisesta näkökulmasta,joka perustuu Marxin lähinnä Pääomassa esittämille kapitalismin teoretisoinnille. Verrattuna taloustieteen imperialistiseen tapaan palauttaa kulttuuriset ilmiöt taloudellisiin, Beech lähtee liikkeelle Marxin tekemästä erottelusta käyttö- ja vaihtoarvojen välillä. Lähtökohta onkin lupaava. Esimerkiksi aiempi puhe taiteen täyttämistä tarpeista ja subjektiivisesti annetuista arvoista viittaa nimenomaan sosiaalisessa prosessissa syntyviin käyttöarvoihin, jotka ovat ainutkertaisia. Käyttöarvot ovat konkreettisia: omenoita taskussa, takki selässä, polkupyörä jalkojen alla. Vaihtoarvo puolestaan perustuu ekvivalenssiin ja on siten abstraktio, joka ilmenee esimerkiksi rahana. Kumpaakaan näistä arvoista ei ole toisesta riippumatta, vaan käytöt artikuloituvat kapitalismissa ainoastaan vaihtoarvojen välittämässä muodossa ja osana hintojen, mielikuvien ja arvostusten kokonaisuutta. Niinpä käytetystä talvitakista ei saa hyvää hintaa kesällä, keväällä aletaan katsella myynnissä olevia pyöriä ja jos syksyllä tekee omenoista siideriä, niiden arvo nousee talven yli. Tämä rakenne on yhtäläisesti konkreettinen ja abstrakti. Marxin kannalta oleellista arvoille kapitalismissa onkin niiden jatkuva metamorfoosi yhdestä muodosta toiseen.

Pä̈omassa monet poliittisen taloustieteen virheistä selitetään erilaisten arvokäsitteiden tiivistymisestä johtuviksi, ja nämä tiivistymät Marx purkaa pääasiassa käyttö- ja vaihtoarvon erottelussa, mutta myös raha-arvon, tavaraarvon, lisäarvon ja niin edelleen kategorioissa. Samalla hän kuitenkin tuo näkyviin, että nämä 
arvot voidaan erottaa toisistaan vain teoreettisesti, koska käytännössä ne esiintyvät aina ketjuuntuneina, ja tämä ketju itse on pääoman kiertoprosessi,järjestelmän ydin. Marxille juuri arvon muuttuminen on kapitalistisen järjestelmän verenkiertoa, ja jos tämä kierto ja muutos pysähtyy, järjestelmä kriisiytyy ja romahtaa. Se, mikä tänään ilmenee korkona, oli eilen sijoitus, ja toissapäivänä tuo sijoitus oli kapitalistin työläiseltä anastamaa palkan lisäarvoa.

Käsitellessään Pääoman I:n osan lopulla niin sanotun alkuperäisen kasautumisen myyttiä Marx antaa kuuluisan kuvauksen pääoman ilmaantumisesta: se "tulee maailmaan tihkuen verta ja likaa kaikista huokosistaan, kiireestä kantapäähän” (Marx 1974, 680). Juuri tätä ennen hän kuitenkin on sanonut, että edellytysten luominen kapitalismin "ikuisille luonnonlaeille" on ollut valtava ponnistus, jonka myötä työläiset on erotettu työvälineistä, elinhyödykkeistä tehty pääomaa ja väestöstä "työtätekeviä köyhiä". Toisin sanoen pääoma ilmaantuu maailmaan saastaisena, mutta puhdistuu heti alkaessaan käskeä villejä töihin. Näistä tulee nyt "työtätekeviä köyhiä", jotka unohtavat aiemman historiansa heti muuttuessaan proletaareiksi. Arvon muodonmuutos, myös raaka-aineiden, työkalujen ja ihmisten muutos sen mukana, on siten kapitalismia eteenpäin sysäävä liike, joka työntää edellään kriisejä ja sotia, ja ajoittain järjestelmä kompastuu näihin rakenteellisiin tuotteisiinsa. Pääoman merkittävä talousteoreettinen ansio onkin se, että se levittää poliittisen taloustieteen siisteiksi kaavoiksi pusertamat talouden"lait" moniin eri suuntiin, osoittaa, että kaavat toimivat siististi vain tietyissä tapauksissa ja tietyin reunaehdoin.

Marxin omat muotoilut eivät myöskään saavuta systemaattista koherenssia. Kiertokulun metamorfoosit ja analyysin monimuotoisuus ovat niitä puolia Pääomassa, jotka Beech kyllä mainitsee, mutta joihin hän ei syvällisetsi paneudu. Hänen ratkaisunsa taiteen arvon kysymykseen seuraa Marxin tuotannon teoriaa. Beech osoittaa, ettei taiteen tuotanto täytä Marxin kapitalistiselle tuotannolle antamia formaaleja piirteitä: koska taiteilija useimmissa tapauksissa omistaa omat työnvälineensä eikä proletarisoidu siinä mielessä, että konkreettisesti myisi työvoimaansa työmarkkinoilla kapitalistille, ei hänen tuottamansa taide ole Marxin määritelmän mukaan tuottavaa. $\mathrm{Pi}$ kemminkin taiteilija on tästä näkökulmasta eräänlainen reliikki, artesaani tai käsityöläinen ilman kiltajärjestelmää. Tältä pohjalta voidaan esittää kysymys, onko taiteilija tavaratuotantoa edeltävän yhteiskuntamuodon jäänne. Yhtäältä kapitalismi todella tarvitsee erilaisia työnmuotoja arvojen muuntamisprosessin raaka-aineeksi, mikä voisi perustella taiteen arvotuotannon poikkeuslaadun kapitalismissa. Kuitenkin taiteellisen työn teknis-teknologinen ja koulutuksellis-sosiaalinen muutos on ollut viimeisten vuosikymmenten aikana valtava, joten taiteen tuotantomallin jälkijättöisyyden painottaminen kapitalismissa ei voi kattaa koko kuvaa arvontuotannon luonteesta taidetyössä. Paradoksaalisesti Beechin pyrkimys muotoilla ohjelma, joka ottaisi huomioon ja kriittisesti vastustaisi valtavirtaisen talousteorian yhdenmukaistavia vaikutuksia taiteen arvolle, näyttää kärsivän niistä Marxin Pääomassa esittämän poliittisen talousteorian kritiikin ambivalensseista, joita länsi-marxistinen ajatteluperinne ja monet muut emansipatoriset diskurssit ovat nostaneet esiin ja pyrkineet korjaamaan. Paradoksaalista tämä on siksi, että Beech puolustaa taiteen erityistä arvoa melko kapean tuotannollisen paradigman kautta, eikä nähdäkseni ota riittävästi huomioon edes Marxin omia jatkokehittelyjä, jotka Pääomassa haastavat alun tuotantonäkökulman. Nähdäkseni Beech selvästi ylenkatsoo sellaisia kriittisiä avauksia, joita marxismin ja feminismin perinteissä on nostettu esiin ideologian, identiteetin, työn muutoksen, subjektifikaation, medioitumisen, sukupuolieron, metropolin ja taiteen diffuusiksi (digitaaliseksi, immateriaaliseksi, sosiaaliseksi jne.) tulemisen teemoihin liittyen.

Beechin luenta marxilaisesta kulttuuriteoriasta kattaa reifikaatioteoriat Georg Lukácsista Adornoon, Guy Debordin spektaakkelista 
Jean Baudrillard'n simulaatioon sekä Antonio Negrin multitudesta Maurizio Lazzaraton immateriaaliseen työhön. Hän tekee kiinnostavan huomion, jonka mukaan nämä teoriat kiinnittävät erityistä huomiota Marxin tavarafetisismin ja tavaramuotoistumisen käsitteisiin. Kapitalistinen tavaratuotanto ja yksinkertainen tarpeita tyydyttävä tavaratuotanto eivät toki ole sama asia, joten taide voi olla "tavaramuotoistunutta, olematta tavaramuotoistunutta”, kuten Beech esittää (commodification without commodification). Yllä mainitut sosiaalisen ja kommodifikaation ajattelijat voisivat huomauttaa, että taiteen erityinen arvo uhkaa Beechin projektissa menettää oman arvonsa, sillä niin monenlaiset arvonlisäyksen metodit vaikuttavat kaikessa siinä, mitä kutsumme taiteeksi, että sen erottaminen kaikesta muusta saattaa tuntua paikoin keinotekoiselta. Joka

\section{VIITTEET}

1. Beechin taiteesta, ks. taideryhmä Freee Art Collectiven kotisivut: https://www.free.org.uk/

2. Kirjoitusta seurasi kiista, sillä Beechin ja Robertsin kritikoimat Andrew Bowie ja J.M Bernstein vastasivat NLR:ssä omilla teksteillään, joihin Beech ja Roberts puolestaan kirjoittivat yhteisvastineen. Kuten tämän myöhemmän kirjoituksen otsikko"Tolerating Impurities: An Ontology, Genealogy and Defence of Philistinism" osoittaa, keskustelu laajeni nopeasti. Artikkelit ja niitä kommentoivat tekstit kolmansilta osapuolilta voi lukea vuonna 2000 julkaistussa kirjassa The Philistine Controversy.

3. Tässä Arts Councilin tarkastelu on valaisevaa.

\section{KIRJALLISUUS}

Beech, Dave (2015): Art and Value. Art's Economic Exceptionalism in Classical, Neoclassical and Marxist Economics. Historical Materialism Book Series, Vol. 94. Leiden, Boston: Brill.

Beech, Dave \& John Roberts (2002): The Philistine Controversy. London, New York: Verso. tapauksessa studiotyöskentelyn, maalausten tekemisen ja yksityisnäyttelyiden mallista olisi jo syytä irrottautua tai kuvaa ainakin laventaa. Huomio kommodifikaation ylimäärittyneisyydestä voidaankin esittää myös Beechille, sillä nimenomaan arvon transformaatiot, joita hän aivan oikein nimittää kommodifikaatio- ja esineellistymisanalyysin sokeiksi pisteiksi, eivät ole hänen omankaan analyysinsa keskiössä.

Taiteen ei-arvon, anti-arvon tai arvoja tuhoavan luonteen kysymys nousee kirjassa esille siellä täällä, mutta teoreettisen luennan keskittyminen Marxin tuotannolliseen puoleen pitää nämä huomiot marginaalissa. ${ }^{4}$ Näissä huomioissa kulkee Art and Valuen raja. Taiteellisen, poliittisen ja miksei talousteoreettisenkin myyräntyön on syytä jatkaa tältä rajalta eteenpin.

\section{—TANELI VIITAHUHTA}

Toistuvien leikkausten alle joutuneen ja vuonna 201030 \% rahoituksestaan menettäneen Englannin Arts Councilin internet-sivut kertovat, että taide tuottaa muiden hyvien vaikutusten lisäksi taloudellista kasvua:"Art and culture [...] benefit us economically, socially, and educationally - from the future prospects of our children, to the vibrancy of our cities, to the contribution made to economic growth.” (http://www.artscouncil.org. uk/why-culture-matters/holistic-case-art-andculture)

4. Tästä aiheesta ks. David Harveyn yritys asettaa kiertokulku ja anti-arvo Marx-tulkinnan keskiöön maailmantalouden näkökulmasta: https://www. youtube.com/watch?v=bgJtWQOzZ-s\&t=820s

Marx, Karl (1948). Pääoma. Kansantaloustieteen arvostelua. Ensimmäinen osa. Suom. O. V. Louhivuori. Helsinki: Kansankulttuuri.

Rose, Margaret A. (1984): Marx's Lost Aesthetic. Karl Marx and the Visual Arts. Cambridge, Cambridge University Press. 